\title{
The Problem of Secularism
}

\author{
Kusuma Dewi Nur Aini \\ Darussalam University Gontor \\ East Java, Indonesia \\ kusumadewi893@yahoo.co.id
}

\begin{abstract}
This paper attempts to discuss discourse regarding secularism. Secularism is an ideology that is as a process of separation between religion and the world. The existence of these ideologies, can eliminate (nihilism) transcendence value in the concept of God in human life. If investigated more deeply, the history of secularism emerges can cause some problems to influence confusion in human life. This can be seen from the social, economic and political fields. First in social life raises a social theory that deals with social life namely Marxism, a theory that teaches about human consciousness how to socialize that affects a very realistic economic attitude. Second in the economic field so that in the process raises capitalism which is one of the manifestations of secularization in the economy. Third, the politics of separation between religion and the state. From these impacts affect human life. The role of Western thinkers also influences the emergence of secularism in human life, so that some Islamic figures criticize the existence of secularism. With the development of secularism in people's lives, it also influences religious attitudes in life. The author finds in this study that secularism greatly influences people's lives, especially in modern times like today. This research will try to elaborate on the events that occurred in ancient times and those that occur today.
\end{abstract}

\section{Keywords-Secularism, Marxism, Capitalism}

\section{INTRODUCTION}

The historian agree that Western Europe has experienced secularism since the last 250 years, as has been described by several Christian theologians. The theologian was the French Jesuits, as Pierre Thielharad de Chardin, who were followed by several other theogues such as Diertich Bonhoeffer from Germany and Paul Tillich from America, they observed that the thoughts occurred at this time has greatly influenced Christian thought, so they began to accept the fact that there was a religious and theological crisis that arose as a result of secularization, Therefore a new ideology arises which greatly influences human life, especially in the fields of sociology, politics and economics. Thus, a new ideology emerges which greatly influences human life, especially in the fields of sociology, politics and economics. Because this is the contradiction of thought to defend from restraint, due to these events Europe suffered a setback and was in the darkness called "The Dark Middle Age" (Dark Middle Ages)". Because some of these events emerged a new Ideology called Secular.

The existence of ideological thinking, when viewed from the aspect of its time, is accompanied by the development of an era of modernization which is a form of change in the form of moral values that affect social life in society. Impacting on an industrial economy, the magnitude of economic activity under socialist conditions will strengthen the bureaucratization process in the economy. However, with these social influences it also results in political freedom. So from the social, economic and political impact, it is not free of historical factors that have experienced setbacks and darkness, one of which is also caused by secularism.

\section{METHODOLOGY}

In this study researchers used two methods to reveal the problem that occurred, first descriptive method, trying to get in Kriste's body, or describing what happened, both methods of analysis, this method was used to describe, something related to secularism in Christianity which made the purpose of the discussion found in the main book or source of data collection, after that goes to analysis.

\section{RESULTS}

The results of this study can be concluded that, The existence of epochs that affect human life also has an impact on people's lives. The impact includes social, economic and political issues. First in social life raises a social theory related to social life namely Marxism, the second in the economic field so that in the process raises Capitalism which is one of the manifestations of secularization in the economy, and the third Politics is the separation between government and the State.

Secularism originated from an ideology that developed in the West, and was defined as human liberation "first from religion and then from metaphysics that governs reason and language of a human being". It is defined as the detachment of the world from false meanings, which is the world that is deprived of religious life in life. In secularization it does not only cover aspects of social and political life, but has influenced aspects of the culture of human life. Caused by the beginning of the disappearance of the religious aspect which is the basis for them. Therefore, from the impact of secularism, so that it does not only affect human life, it even affects people's lives, especially in their religious side.

This explanation will explain the various impacts of the 3 factors that influence it due to secularization, namely social, economic and political issues. Because secularism is an ideology that is only focused on worldliness rather than spiritual or religious. From this it affects the attitude of human life in interacting with others and influences the attitudes of society, therefore the researcher tries to express and analyze the impact of secularism in Christianity.

\section{A. Social}

Modern humans live in a social world with various circumstances that exist, so that sometimes there will be a debate and the existence of values that are not suitable in life. With that humans have the right to determine a choice in real life. For example they have the right to maintain a job that they want, from this they will get high dignity before the community. Due to social status is a form of position in the 
community system that affects their lives. The existence of social life so that people want to do something free to choose their way of life. From this there arises one of the problems in the life of modern society in humans which greatsly affects them, especially in the life of society.

Modernization is a new term for a long process of social change, in which underdeveloped people acquire characteristics that are common to more developed societies. Many opinions say that modernization as a change of view varies. Light and Kaller, mean modernization as a change in values, institutions and views that move traditional communities towards industrialization and urbanization. Modernization also has several other aspects that occur in society, namely secularization, educational democracy, media participation. Because the emergence of some of these aspects affects social life.

Social life is one of the ways humans interact with one another and to connect with other people, and to create a thought These thoughts greatly affect society. Because what happens to humans will be very influential in their lives. Religion as a controller of human life to maintain human life so as not to make social life. Therefore, the role of Religion is very important to balance social life in society. Social influence that occurs in society with the existence of secularization, also raises a social theory related to social, economic and political life. Namely the theory of Marxism. The one who brought this theory was Karl Marx. Karl Marx was a Protestant socialist, because he had to be a socialist, because at first he had to deal with the industrialists so that he became a socialist figure, and he thought that the source of human problems basically lay in private property. Human problems arise in the background behind the level of strata between rich people with increasingly luxurious life while the poor or workers are increasingly full of misery. From the injustice that Karl Marx felt disturbing his conscience so that it changed radically, so that he brought up the thoughts that were focused on Marxism. Therefore, it can be concluded that with the existence of social phenomena that occur in the community, it raises a new theory of Marxism.

The theory of Marxism also teaches about human consciousness how humans in socializing influence economic attitudes that are very real. The existence of this theory as Karl Marx's attempt to improve human lives from the oppression they experienced and the arbitrary actions they received. Therefore, with this theory Karl Marx that emerged in the life of the Christian community, is a solution for their people to improve their lives, to be better at what they experienced before with the violence and abuse they experienced.

\section{B. Economic}

In the view of social life in society, it does not escape the state of an economy, which occurs in an environment of life. Just as Karl Marx said that the economy is the determinant of the life of social change. Because Economics is a goal to meet the needs and desires of the community to improve the welfare of the community. So if concluded the economy can be interpreted as an activity to achieve a prosperity in the community.

The economic activity that occurs in the world is also influenced by the existence, a rock theory introduced by Weber's existence of secularization. In the process of secularization raises Capitalism which is one of the manifestations of secularization in the economy, as well as giving birth to a social life order that influences the economy, politics and religion In the secular world of religion is one of the interpersonal spaces than he is public. Peter L. Berger, said that secularization is a process driven by Protestantism and Capitalism. The secularization of the economy comes from:

"In an economic sector is the formation of a capitalistic and industrial process, while secularization has come out of a regional order in society. Because of this incident religion seems to be isolated in the most personal or public sphere of life from international order, especially in state and religious institutions ".

There are various social phenomena that occur, which are mixed with the political system, so that various symptoms occur. The people's life system began to be ambiguous. Especially in the economy, for example, with the free market itself, as well as the consensus in the exchange of freely freely. The rise of economic cases has also strangled people's lives, the poor are getting poorer, the prosperous, the more prosperous, with the establishment of a free market that is capitalistic in nature. From this it can be concluded that with the development of modern times resulted in changes in human mindset and human behavior in looking at the world.

Modernization has changed the way of understanding in human life, because of secularization. Some figures also agreed that secularization and secularism exist because of modernization, which causes the attitude of society who tend to be materialistic, rational, pramatik, and demand the realization of everything in life. Aguste Coumte also stated that as a result of modernization, society would grow beyond the "theological stage" so that when the social revolution of religion would be abandoned in people's lives. From the influence of modernization that makes secularization, which has an impact on human life.

The existence of a modern secular society now also influences traditional political systems towards a moderm. From this modern secularism increasingly characterizes their lives which include, First, the existence of government separation from religious ideologies and ecclesiastic structures, Second, the expansion of government to carry out functions in regulation in the socio-economic field which was originally handled by religion, Third, the establishment of secular political values. In these three aspects it is universal that has been carried out by modern secular societies. Especially what happens in governments that hold fast to secularization, has found a solution achieved without the constraints that occur. Therefore secularization can achieve a political culture with courage so that a problem occurs. Thus we can add these aspects to four, namely trust in power and religious practices

\section{Politics}

Modernization has changed the way of understanding in human life, because of secularization. Some figures also agreed that secularization and secularism exist because of modernization, which causes the attitude of society who tend to be materialistic, rational, pramatik, and demand the realization of everything in life. Aguste Coumte also stated that as a result of modernization, society would grow beyond the "theological stage" so that when the social revolution of religion would be abandoned in people's lives. From the 
influence of modernization that makes secularization, which has an impact on human life.

The existence of secular modern society now also influences traditional political systems towards a moderm. From this modern secularism increasingly characterizes their lives which include, First, the existence of government separation from religious ideologies and ecclesiastic structures, Second, the expansion of government to carry out functions in regulation in the socio-economic field which was originally handled by religion, Third, the establishment of secular political values. In these three aspects it is universal that has been carried out by modern secular societies. Especially what happens in governments that hold fast to secularization, has found a solution achieved without the constraints that occur. Therefore secularization can achieve a political culture with courage so that a problem occurs. Thus we can add these aspects to four, namely trust in power and religious practices. Therefore these symptoms cause a prolema in life, especially what happens to Christians.

\section{CONCLUSION}

Secularism is the result of contradictory modern thought, because it separates religion and state, or sets aside elements to theology in the elements of human life. This article recommends more specific research on the problems faced by society due to secularism. The secularism problems that must be faced in the social, economic and political fields are as follows:

1. Social, As for the impact that led to secularization, with the emergence of extreme human thought with the presence of parties to compete for power and also greatly glorify social status. From this raises a theory in social life called the Theory of Marxism. The theory of Marxism is the theory taught by Karl Marx, while Marxism also teaches about human consciousness how humans are in socializing, which is related to Economics.

2. Economy, the impact that led to secularization, with the existence of a new theory of capitalism. Capitalism is the sale that occurs in the free market.
3. Politics, As for the effects that bring about secularization, in the field, there is a separation between the State and politics.

With this explanation, it can be concluded that the secularism of the emergence of capitalism influences economic life so that it also influences human welfare. From this, some communities disagree with this, thus giving rise to the Marxist Theory, to defend their social life.

\section{REFERENCES}

[1] Audi, Robert, Agama dan Nalar Sekuker dalam Masyarakat Libera, Penerjemah: Yusdani dan Aden Wijaya, Penerbit UII Press Yogyakarta (anggota IKAPI)

[2] Backry,Oemar,Islam menentang sekularisme, Penerbit: Mutiara Jakarta

[3] Cox,Harvey The Secular City, In the United Kingdom:Princenton University Press, 6 Oxford Street, Woodstock, Oxfordshire OX2o iTW

[4] F., Peklanof, Masalah-masalah Dasar Marxisme, Fundamental problem Marxisme, Penerjemah Ira Manto

[5] Idris ,Amiruddin, Ekonomi Publik, Penerbit DEEPUBLISH (Grub Penerbitan CV BUDI UTA Amiruddin Idris, Ekonomi Publik, Penerbit DEEPUBLISH (Grub Penerbitan CV BUDI UTAMA), h:1MA)

[6] Irawan, I.B. Teori-teori Sosial dalam Tiga Paradigma (Fakta Sosial, Definisi Sosial, dan Perilaku Sosial), Edisi Pertama Copright 2012, Penerbit: Pranadamedia Grub

[7] J. Blasi, Anthony, Sociology of Religion in America, ( A History of a Secular Fascination with Religion

[8] Karim, M. Rusli, Agama Modernisasi dan sekularisasi,1994 Yogyakarta: Tiara wacanaJogja.

[9] L. Berger, Peter, The Sacred Canopy: Elements of a SociologicalTheory of Religion 1969 (New York: Doubleday \& Company)

[10] Peklanof, G.F., Masalah-masalah Dasar Marxisme, Fundamental problem Marxisme, Penerjemah Ira Manto.

[11] Rd. Datoek A., Pachoer, Sekularisasi dan Sekularisme Agama,1 (September 2016).Religious: Jurnal Agama dan Lintas Budaya 1.

[12] S. Turner, Bryan, Menggugat Sosiologi Sekuler (Studi Analisis Atas SosiologiWeber), Cetakan Pertama: Agustus 2005Penerbit Suluh Press.

[13] Smith,Donald Eugene,Agama di tengah Sekularisasi Politik, Pengantar: Dr: Nurcholisch Mdjid, Penerbit pustaka panjimas, Jakarta, 1985-(1999) Stark Rodney, “ Secularism R.I.P” Sociology of religion 60, no. 3 .

[14] Stark, “ Rodney Secularism R.I.P” Sociology of religion 60, no. 3 (1999), h:250

[15] Waluya, Badja, Sosiologi Menyelami fenomena kehidupan Masyarakat,2007 Penerbit: PT Selia Purna Inves, Cetakan I, Juni. 